\title{
Observations on intravenous administration of lignocaine in patients with myocardial infarction
}

\author{
N. P. S. CAMPBEll, J. G. Kelly, A. A. J. ADGEY, D. G. MCDEVitT, AND \\ J. F. PANTRIDGE
}

From the Department of Cardiology, Royal Victoria Hospital and Queen's University, Belfast, and Department of Therapeutics and Pharmacology, Queen's University, Belfast

SUMMARY Lignocaine was administered intravenously to 36 patients with acute myocardial infarction.

A bolus of $100 \mathrm{mg}$ followed by an infusion of $2 \mathrm{mg} / \mathrm{minute}$ failed to maintain plasma levels above $2 \mu \mathrm{g} / \mathrm{ml}$. A bolus of $100 \mathrm{mg}$ followed by $4 \mathrm{mg} / \mathrm{minute}$ also failed to maintain satisfactory plasma concentrations during the first hour of therapy.

A bolus of $75 \mathrm{mg}$ was combined with an infusion of $10 \mathrm{mg} /$ minute for 20 minutes followed by $1.5 \mathrm{mg} /$ minute. Satisfactory plasma concentrations during the first hour were observed in 94 per cent of the estimations. No important adverse side effects occurred during the infusion of $10 \mathrm{mg} /$ minute.

Lignocaine has been found to be relatively ineffective in controlling ventricular arrhythmias occurring immediately after the onset of acute myocardial infarction (Geddes et al., 1972). This may be related in some cases to the presence of sympathetic overactivity in the acute phase of myocardial infarction since the drug has been shown to be more effective when the heart rate is within the normal range (Pantridge et al., 1974). However, failure to achieve adequate plasma concentrations may be an important reason for therapeutic ineffectiveness. It has been said that plasma concentrations of lignocaine of 2 to $5 \mu \mathrm{g} / \mathrm{ml}$ are usually effective (Koch-Weser, 1972). In this study, the plasma concentrations of lignocaine obtained with conventional doses of the drug have been investigated. We have used a theoretical approach to design a regimen that might give therapeutic plasma concentrations, particularly throughout the first hour of therapy.

\section{Patients and methods}

Thirty-six patients were studied (Table 1). All received lignocaine because of ventricular arrhythmias complicating acute myocardial infarction. Six had self-terminating ventricular tachycardia. The remainder had ventricular extrasystoles (frequent, consecutive, or $R$ on $T$ ). The drug was given to all patients within 48 hours of the onset of symptoms

Received for publication 9 January 1978 of infarction (median 10 hours). Twenty-six (72\%) of the patients had clinical or radiographic evidence of left ventricular failure when treatment was started. None had pulmonary oedema or cardiogenic shock.

The 36 patients were divided into 4 groups. Group 1 (10 patients) received an initial $100 \mathrm{mg}$ injection of lignocaine over 30 seconds. This was followed immediately by a continuous infusion of the drug at a rate of $2 \mathrm{mg} /$ minute. Groups 2 and 3 (each containing 10 patients) also received an initial $100 \mathrm{mg}$ injection but this was followed by a $4 \mathrm{mg}$ / minute infusion for 20 and 45 minutes, respectively. The rate of infusion was then reduced to $2 \mathrm{mg} /$ minute. Group 4 (6 patients) received an initial $75 \mathrm{mg}$ injection of lignocaine given over 30 seconds followed by a $10 \mathrm{mg} / \mathrm{minute}$ infusion for $20 \mathrm{~min}$ utes. The infusion rate was then reduced to $1.5 \mathrm{mg} /$ minute. The regimen in Group 4 was devised using the method of Wagner (1974). Wagner suggested that a drug might be given intravenously using 2 different infusion rates-an initial rapid rate $\left(Q_{1}\right)$ and a later slower rate $\left(Q_{2}\right) . Q_{2}$ is calculated from the clearance of the drug and the desired final plasma concentration. A concentration of $3 \mu \mathrm{g} / \mathrm{ml}$ was chosen as this lies near the centre of the therapeutic range ( 2 to $5 \mu \mathrm{g} / \mathrm{ml}$ ). $Q_{1}$ is then derived from $\mathrm{Q}_{2}$ and the half-life of elimination of the drug. Details of the calculation are shown in the Appendix.

Throughout the study, lignocaine was given through an arm vein. Samples were withdrawn through an indwelling cannula from a vein in the 
Table 1 Details of patients receiving various intravenous doses of lignocaine

\begin{tabular}{|c|c|c|c|c|c|c|c|c|c|c|c|c|c|}
\hline & & \multirow{2}{*}{$\begin{array}{l}\text { Age } \\
(y)\end{array}$} & \multirow{2}{*}{$\begin{array}{l}\text { Sex } \\
M\end{array}$} & \multirow{2}{*}{$F$} & \multirow{2}{*}{$\begin{array}{l}\text { Weight } \\
\text { kg }\end{array}$} & \multirow{2}{*}{$\begin{array}{l}\text { Urea } \\
\left(\mathrm{mg} \mathrm{g}^{\star}\right. \\
(100 \mathrm{ml})\end{array}$} & \multicolumn{4}{|c|}{ Site of infarction } & \multirow{2}{*}{$\begin{array}{l}\text { Time from } \\
\text { onset of } \\
\text { symptoms } \\
(h)\end{array}$} & \multirow{2}{*}{$\begin{array}{l}\text { No. with } \\
\text { previous } \\
\text { infarction }\end{array}$} & \multirow[t]{2}{*}{ Total } \\
\hline & & & & & & & Ant & Post & $L B B B$ & $S E$ & & & \\
\hline \multicolumn{14}{|c|}{$\begin{array}{l}\text { Single injection } \\
\text { with continuous } \\
\text { infusion }\end{array}$} \\
\hline Group 1 & $\begin{array}{l}\text { Mean } \\
\text { SEM }\end{array}$ & $\begin{array}{l}57 \\
\pm 2 \cdot 6\end{array}$ & 9 & 1 & $\begin{array}{l}72 \\
\pm 3.5\end{array}$ & $\begin{array}{l}36 \\
\pm 2 \cdot 6\end{array}$ & 6 & 4 & 0 & 0 & $\begin{array}{l}13 \\
\pm 4 \cdot 8\end{array}$ & 2 & 10 \\
\hline Group 2 & $\begin{array}{l}\text { Mean } \\
\text { SEM }\end{array}$ & $\begin{array}{l}55 \\
\pm 3.0\end{array}$ & 8 & 2 & $\begin{array}{l}70 \\
\pm 1 \cdot 8\end{array}$ & $\begin{array}{l}34 \\
\pm 3 \cdot 3\end{array}$ & 6 & 4 & 0 & 0 & $\begin{array}{l}11 \\
\pm 2 \cdot 0\end{array}$ & 0 & 10 \\
\hline Group 3 & $\begin{array}{l}\text { Mean } \\
\text { SEM }\end{array}$ & $\begin{array}{l}60 \\
\pm 1.9\end{array}$ & 8 & 2 & $\begin{array}{l}74 \\
\pm 2 \cdot 7\end{array}$ & $\begin{array}{l}41 \\
\pm 5 \cdot 4\end{array}$ & 6 & 3 & 0 & 1 & $\begin{array}{l}15 \\
\pm 3 \cdot 3\end{array}$ & 1 & 10 \\
\hline \multirow[t]{2}{*}{ Group 4} & $\begin{array}{l}\text { Mean } \\
\text { SEM }\end{array}$ & $\begin{array}{l}50 \\
\pm 4 \cdot 0\end{array}$ & 6 & 0 & $\begin{array}{l}79 \\
\pm 3 \cdot 2\end{array}$ & $\begin{array}{l}33 \\
\pm 3 \cdot 1\end{array}$ & 4 & 2 & 0 & 0 & $\begin{array}{l}19 \\
\pm 5 \cdot 5\end{array}$ & 1 & 6 \\
\hline & & & & & & & & & & & & & 36 \\
\hline
\end{tabular}

Ant $=$ anterior Post $=$ posterior $;$ LBBB $=$ left bundle-branch block; SE = subendocardial; SEM $=$ standard error of mean .

$\star 1 \mathrm{mg} / 100 \mathrm{ml} \approx 0166 \mathrm{mmol} / 1$.

other arm. Blood pressure was measured by sphygmomanometer before and 5 and 15 to 20 minutes after the lignocaine was given. The cardiogram was observed on an oscilloscope throughout the study.

The samples for measurement of the plasma concentration of lignocaine were taken $3,6,10$, $15,20,25,30,45,60,120$, and 240 minutes after the initial injection. The rate of infusion was controlled by an IVAC 501 drip counter or a Braun constant infusion pump (Type 871010). Lignocaine hydrochloride BP (the monohydrated form, $\mathrm{C}_{14} \mathrm{H}_{22} \mathrm{~N}_{2} \mathrm{O}, \mathrm{HCl}, \mathrm{H}_{2} \mathrm{O}$ molecular weight $288 \cdot 8$ ) was used throughout the study.

All blood samples were centrifuged and the plasma stored at $-20^{\circ} \mathrm{C}$. Analysis was subsequently performed using gas liquid chromatography. The plasma was made alkaline and the lignocaine was extracted with ether. After evaporation of the ether and reconstitution with dichloroethane, aliquots were injected into a gas chromatographic column. The column was packed with 2 per cent carbowax $20 \mathrm{M}$ on $\mathrm{KOH}$-treated chromosorb G. Diphenhydramine was used as an internal standard.

Statistical comparisons of mean values were performed using Student's unpaired $t$ test. Comparisons within groups were made using Student's paired $t$ test.

\section{Results}

There were no statistically significant differences in age, sex, blood urea, or time from onset of symptoms to administration of the drug among the patients in groups 1 to 4 (Table 1). Patients in group 4 were significantly heavier than those in group $2(P<0.05)$.

The mean plasma concentrations achieved are compared in Figs. 1 and 2 . When a $4 \mathrm{mg} /$ minute infusion was given after an initial $100 \mathrm{mg}$ injection (groups 2 and 3 ) the mean concentrations during the first 20 minutes did not differ significantly from those among patients in group $1(100 \mathrm{mg}$ followed by a $2 \mathrm{mg} /$ minute infusion) (Fig. 1). However, 45 minutes after the initial injection, patients in group 1 had a significantly lower mean plasma concentration than the patients in group $3(P<$ $0 \cdot 05)$. No significant differences occurred between the mean plasma concentrations of patients in groups 2 and 3 . One patient in group 2 attained a concentration $>7 \mu \mathrm{g} / \mathrm{ml}$ after 15 minutes. After a small initial fall, the mean plasma concentrations for group 4 patients steadily climbed during the first 20 minutes, in 1 patient reaching $9.3 \mu \mathrm{g} / \mathrm{ml}$ at 20 minutes (Fig. 2). The mean concentrations from 10 minutes to 1 hour after the initial injection for patients in group 4 differed significantly from those in group $1(P<0.05)$. At 2 and 4 hours, there were no significant differences between any of the groups (Figs. 1 and 2).

In patients in group 147 per cent of the plasma concentrations were less than $2 \mu \mathrm{g} / \mathrm{ml}$ during the first hour of treatment (Table 2). All but 1 of the patients in group 1 had at least 1 plasma concentration $<2 \mu \mathrm{g} / \mathrm{ml}$ during the first hour of treatment. Only 52 per cent of the concentrations were in the 


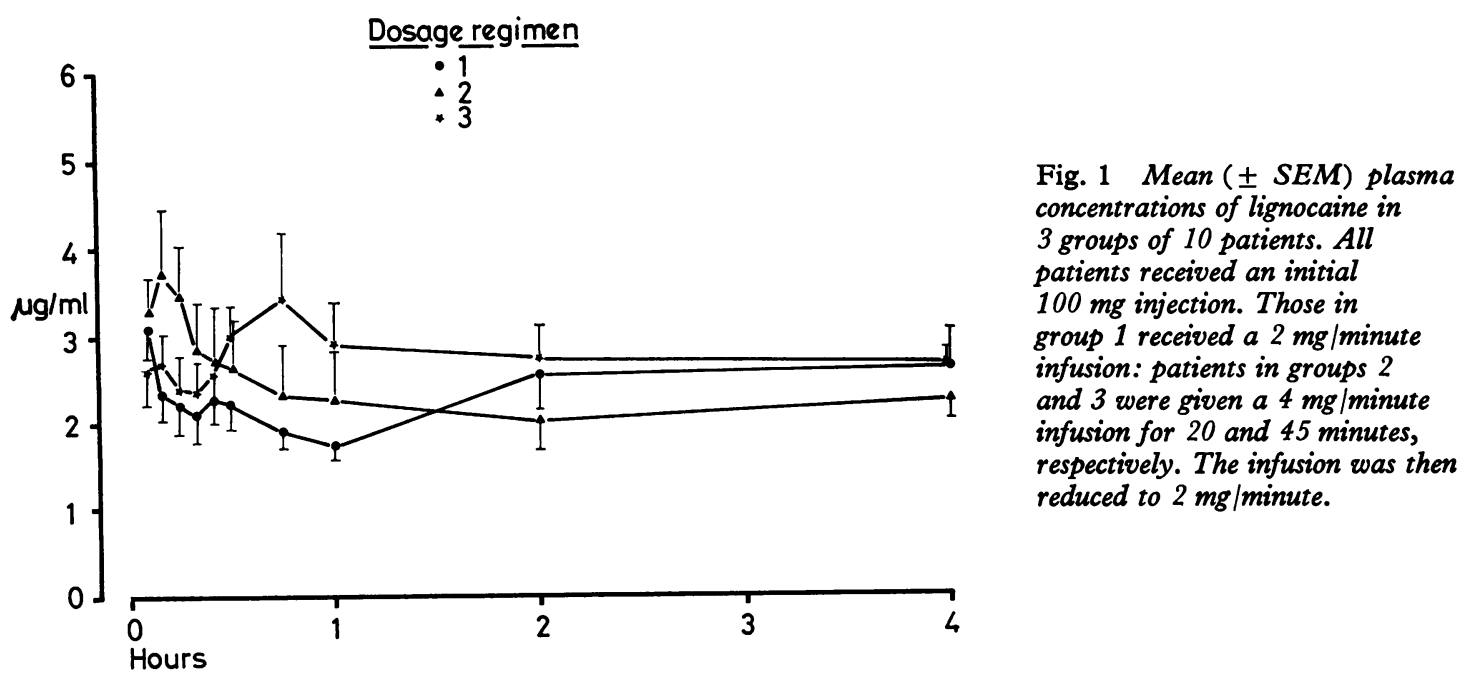

range 2 to $5 \mu \mathrm{g} / \mathrm{ml}$. In groups 2 and 3, the percentages within this range were 47 and 65 , respectively. In group 4, only 6 per cent of the plasma concentrations were below $2 \mu \mathrm{g} / \mathrm{ml}$.

Apart from numbness in the tongue, paraesthesiae, and dizziness after the initial bolus and drowsiness during the continuous infusion, adverse neurological effects were not encountered. Suspected adverse haemodynamic effects caused the drug to be stopped in 4 patients. None of these suspected adverse effects occurred within the first 90 minutes of treatment. Two of these patients (1 from group 1 and 1 from group 2) developed bradycardia and hypotension. One of these developed complete heart block. Both had shown bradycardia before the administration of lignocaine. One patient (from group 4) developed increasing sinus tachycardia and congestive heart failure and in another (from group 1) the systolic blood pressure fell from 85 to $70 \mathrm{mmHg}$. Since the suspected adverse haemodynamic effects occurred in association with plasma concentrations of lignocaine $<3 \mu \mathrm{g} / \mathrm{ml}$, they cannot be definitely attributed to the treatment.

In the groups receiving the 4 and $10 \mathrm{mg} /$ minute infusions, a significant mean increase in the mean arterial pressures of 4.8 and $9 \mathrm{mmHg}$, respectively, was observed after 15 to 20 minutes $(P<0.05)$.

Recurrent arrhythmias were detected in 5 patients. Important ventricular extrasystoles were observed in 3 and ventricular tachycardia in 2 . In only 1 of the 5 was the plasma concentration $>2 \mu \mathrm{g} / \mathrm{ml}$. These arrhythmias occurred more than 2 hours after the onset of therapy.

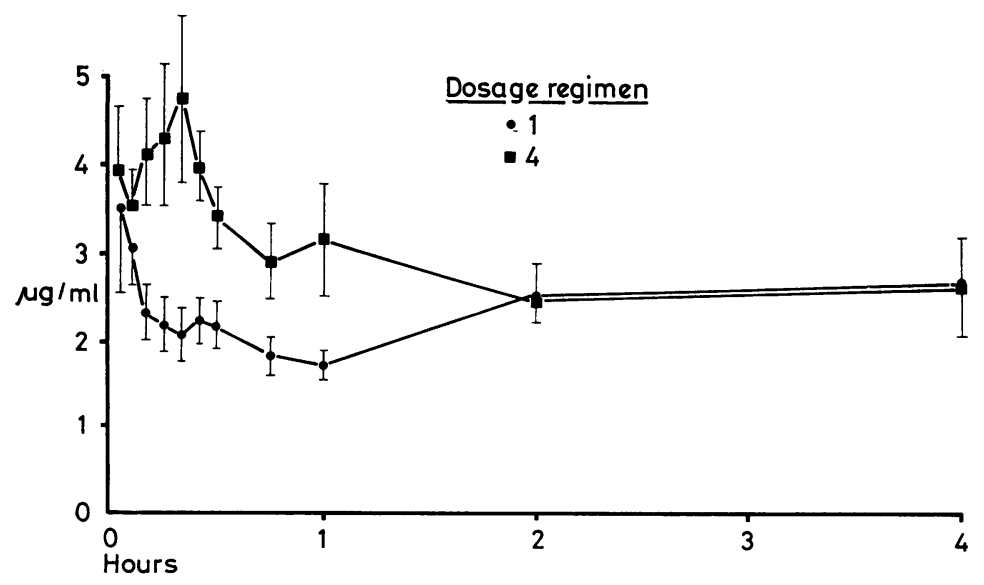

Fig. 2 Mean ( $\pm S E M)$ plasma concentrations of lignocaine in 16 patients. Group 1 (10 patients) received a $100 \mathrm{mg}$ bolus followed by a $2 \mathrm{mg} /$ minute infusion. Group 4 ( 6 patients) received a $75 \mathrm{mg}$ bolus and a $10 \mathrm{mg} / \mathrm{minute}$ infusion for 20 minutes: the infusion was then reduced to $1.5 \mathrm{mg} /$ minute. 
Table 2 Distribution of plasma concentrations of lignocaine during first hour of treatment

\begin{tabular}{llll}
\hline Group & \multicolumn{3}{l}{$\%$ of plasma concentrations } \\
\cline { 2 - 4 } & $<2 \mu \mathrm{g} / \mathrm{ml}$ & 2 to $5 \mu \mathrm{g} / \mathrm{ml}$ & $>5 \mu \mathrm{g} / \mathrm{ml}$ \\
\hline 1 & 47 & 52 & 1 \\
2 & 35 & 47 & 18 \\
3 & 24.5 & 65 & 10.5 \\
4 & 6 & 76.5 & 17.5 \\
\hline
\end{tabular}

\section{Discussion}

This study shows that plasma concentrations of lignocaine of $<2 \mu \mathrm{g} / \mathrm{ml}$ are commonly observed during the initial hour of therapy when a bolus injection of $100 \mathrm{mg}$ is combined with a $2 \mathrm{mg} /$ minute infusion. Other workers have observed a fall in plasma concentrations below therapeutic levels when a single bolus injection is followed by an infusion of 2 to $3 \mathrm{mg} /$ minute (Bassan et al., 1974; Greenblatt et al., 1976). Low plasma concentrations of lignocaine may be hazardous. Gamble and Cohn (1972) have indicated that after experimental coronary artery ligation, plasma concentrations of $<2 \mu \mathrm{g} / \mathrm{ml}$ may enhance re-entrant arrhythmias. Geddes et al. (1974) described the effects of lignocaine on a re-entrant model where hot and cold lesions were produced on the right ventricular wall of open chest dogs. Re-entry increased as the effect of the intravenous bolus injections of the drug diminished. Geddes et al. (1972) described increased frequency of ventricular ectopic activity when $100 \mathrm{mg}$ followed by a $2 \mathrm{mg} /$ minute infusion of lignocaine was given to patients within 4 hours of the onset of acute myocardial infarction.

The data in this study indicate that when the bolus was followed by a $4 \mathrm{mg} /$ minute infusion, the infusion rate had to be maintained for 45 minutes to give a mean plasma concentration significantly higher than that obtained with a $2 \mathrm{mg} /$ minute infusion. Furthermore, with this regimen nearly one-quarter $(24.5 \%)$ of the plasma concentrations during the first hour of treatment were potentially ineffective $(<2 \mu \mathrm{g} / \mathrm{ml})$. To overcome this problem the approach suggested by Wagner in 1974 was adopted. Using this regimen, only 6 per cent of the concentrations during the first hour were $<2$ $\mu \mathrm{g} / \mathrm{ml}$. During the first hour of therapy, the mean plasma concentrations were either greater than or approximated to $3 \mu \mathrm{g} / \mathrm{ml}$. However, 17.5 per cent of the plasma concentrations during the first hour of treatment were $>5 \mu \mathrm{g} / \mathrm{ml}$ and in 1 patient a concentration of $9.3 \mu \mathrm{g} / \mathrm{ml}$ was obtained during the $10 \mathrm{mg} / \mathrm{minute}$ infusion. After the infusion rate was reduced to $1.5 \mathrm{mg} /$ minute at 20 minutes, the plasma concentration fell rapidly.
Despite the high plasma concentrations, no important adverse reactions occurred during high infusion rates. However, with infusion rates of 4 and $10 \mathrm{mg} /$ minute, a significant increase in mean arterial pressure was observed. Such increases have been described in previous reports and have been attributed to an increased sensitivity to circulating catecholamines (Grossman et al., 1969).

Since there is considerable variation in kinetics observed in patients with acute myocardial infarction and as low plasma clearances were used for calculation of the regimen from Wagner's (1974) theoretical approach, it is not surprising that concentrations after 1 hour fell during the $1.5 \mathrm{mg} /$ minute infusion. In all 6 patients in group 4, the mean 4-hour plasma concentration was 54 per cent of the peak concentration after 20 minutes. This suggests that a higher infusion rate than $1.5 \mathrm{mg} /$ minute should have been given 20 minutes after the initiation of treatment.

Other regimens have been suggested to maintain effective plasma concentrations during the early hours of treatment with lignocaine. Collinsworth et al. (1974) suggested that an initial small bolus injection $(0.75 \mathrm{mg} / \mathrm{kg})$ might be given and a similar dose administered 15 minutes later. However, using this approach, the fall in plasma concentrations after the first injection may not be prevented (Greenblatt et al., 1976) and very high plasma concentrations may occur after the second injection. Aps et al. (1976) suggested an initial bolus of 75 to $100 \mathrm{mg}$ intravenously followed by a $4 \mathrm{mg} /$ minute infusion for 30 minutes, $2 \mathrm{mg} /$ minute for 2 hours, and $1 \mathrm{mg} /$ minute thereafter. They found that the mean plasma concentration 'within a few minutes' of the initial injection was approximately $1.8 \mu \mathrm{g} / \mathrm{ml}$. More recently, Levy et al. (1977) have reported a regimen without an initial bolus in which 200,250, or $300 \mathrm{mg}$ lignocaine was infused at $25 \mathrm{mg} /$ minute. This was followed by a slower rate of infusion. Plasma concentrations were not determined during the 8 to 12 minutes of rapid infusion. Because of the absence of an initial bolus injection, this method is less suitable for the immediate correction of rhythm disturbances. Sheridan et al. (1977) have reported the use of the combination of single intravenous and intramuscular injections of lignocaine. Plasma concentrations of $2 \mu \mathrm{g} / \mathrm{ml}$ or greater were obtained in all patients throughout the first hour of treatment. Nevertheless, the intramuscular route has the disadvantage that the rate of absorption varies with the injection site and the blood flow at the site (Schwartz et al., 1974; Evans et al., 1975). Furthermore, should complications such as atrioventricular block develop, a large depot of lignocaine might be hazardous. 


\section{Appendix}

\section{Calculations of therapeutic regimen for group 4}

Wagner (1974) in designing an intravenous dosage regimen suggested that a constant rate infusion $\left(Q_{1}\right)$ can be given over a short period of time ( $\mathrm{T}$ hours $=0.25-3$ hours). The infusion rate is then abruptly reduced to a second speed $\left(Q_{2}\right)$ which is maintained as long as required. $Q_{2}$ is calculated from the clearance and the desired plasma concentration. The ratio $Q_{1} / Q_{2}$ is estimated using the relation $\mathrm{Q}_{1} / \mathrm{Q}_{2}=0.5+1.443\left(\mathrm{t} \frac{1}{2} / \mathrm{T}\right)$ where $t \frac{1}{2}=$ the plasma elimination half-life and $T=$ the time over which an infusion rate of $Q_{1}$ is to be given. The longest half-life and the lowest plasma clearance cited by Prescott and Nimmo (1971) in patients after myocardial infarction were 4.4 hours and $280 \mathrm{ml} /$ minute respectively. From these figures $Q_{2}$ approximated to $1.5 \mathrm{mg} /$ minute. During the present study, a plasma concentration of $3 \mu \mathrm{g} / \mathrm{ml}$ was considered desirable. 0.33 hours was selected as a suitable value for $T$. Using these data, a value of $16.5 \mathrm{mg} /$ minute for $Q_{1}$ was calculated, that is $330 \mathrm{mg}$ to be administered over the first 20 minutes. To reduce the risk of toxicity, this dose was reduced to a $75 \mathrm{mg}$ bolus followed by a $10 \mathrm{mg} /$ minute infusion for 20 minutes (total dose $275 \mathrm{mg}$ ).

\section{References}

Aps, C., Bell, J. A., Jenkins, B. S., Poole-Wilson, P. A., and Reynolds, F. (1976). Logical approach to lignocaine therapy. British Medical fournal, 1, 13-15.

Bassan, M. M., Weinstein, S. R., and Mandel, W. J. (1974). Use of lidocaine by continuous infusion. American Heart fournal, 87, 302-303.

Collinsworth, K. A., Kalman, S. M., and Harrison, D. C. (1974). The clinical pharmacology of lidocaine as an antiarrhythmic drug. Circulation, 50, 1217-1230.

Evans, E. F., Proctor, J. D., Fratkin, M. J., Velandia, J., and Wasserman, A. J. (1975). Blood flow in muscle groups and drug absorption. Clinical Pharmacology and Therapeutics, 17, 44-47.

Gamble, O. W., and Cohn, K. (1972). Effect of propranolol, procainamide, and lidocaine on ventricular automaticity and re-entry in experimental myocardial infarction.
Circulation, 46, 498-506.

Geddes, J. S., Webb, S. W., and Adgey, A. A. J. (1974). Effect of lidocaine on 'gating' mechanism. American Heart fournal, 88, 260-261.

Geddes, J. S., Webb, S. W., and Pantridge, J. F. (1972). Limitations of lignocaine in control of early ventricular dysrhythmias complicating acute myocardial infarction (abstract). British Heart fournal, 34, 964-965.

Greenblatt, D. J., Bolognini, V., Koch-Weser, J., and Harmatz, J. S. (1976). Pharmacokinetic approach to the clinical use of lidocaine intravenously. Fournal of the American Medical Association, 236, 273-277.

Grossman, J. I., Cooper, J. A., and Frieden, J. (1969). Cardiovascular effects of infusion of lidocaine on patients with heart disease. American fournal of Cardiology, 24, 191-197.

Koch-Weser, J. (1972). Antiarrhythmic prophylaxis in ambulatory patients with coronary heart disease. Archives of Internal Medicine, 129, 763-772.

Levy, R. A., Charuzi, Y., and Mandel, W. J. (1977). Lignocaine: a new technique for intravenous administration. British Heart fournal, 39, 1026-1028.

Pantridge, J. F., Webb, S. W., Adgey, A. A. J., and Geddes, J. S. (1974). The first hour after the onset of acute myocardial infarction. In Progress in Cardiology 3, pp. 173-188. Ed. by P. N. Yu and J. F. Goodwin. Lea and Febiger, Philadelphia.

Prescott, L. F., and Nimmo, J. (1971). Plasma lidocaine concentrations during and after prolonged infusions in patients with myocardial infarction. In Lidocaine in the Treatment of Ventricular Arrhythmias, pp. 168-177. Ed. by D. B. Scott and D. G. Julian. E. and S. Livingstone, Edinburgh and London.

Schwartz, M. L., Meyer, M. B., Covino, B. G., Narang, R. M., Sethi, V., Schwartz, A. J., and Kamp, P. (1974). Antiarrhythmic effectiveness of intramuscular lidocaine: influence of different injection sites. Fournal of Clinical Pharmacology, 14, 77-83.

Sheridan, D. J., Crawford, L., Rawlins, M. D., and Julian, D. G. (1977). Antiarrhythmic action of lignocaine in early myocardial infarction. Plasma levels after combined intramuscular and intravenous administration. Lancet, 1, 824-825.

Wagner, J. G. (1974). A safe method for rapidly achieving plasma concentration plateaus. Clinical Pharmacology and Therapeutics, 16, 691-700.

Requests for reprints to Dr A. A. J. Adgey, Department of Cardiology, Royal Victoria Hospital, Grosvenor Road, Belfast BT12 6BA, Northern Ireland. 